\title{
GPS results for Macedonia and its importance for the tectonics of the Southern Balkan extensional regime
}

\author{
B. Clark Burchfiel ${ }^{\mathrm{a}, *}$, Robert W. King ${ }^{\mathrm{a}}$, Angel Todosov ${ }^{\mathrm{b}}$, Valentin Kotzev ${ }^{\mathrm{c}}$, \\ Nikola Durmurdzanov ${ }^{d}$, Todor Serafimovski ${ }^{\mathrm{d}}$, Bilbil Nurce ${ }^{\mathrm{e}}$ \\ ${ }^{a}$ Massachusetts Institute of Technology, Cambridge, MA, USA \\ ${ }^{\mathrm{b}}$ Mladinska 19, Strumica, Macedonia \\ ${ }^{c}$ Central Laboratory of Geodesy, Bulgarian Academy of Sciences, Sofia, Bulgaria \\ ${ }^{\mathrm{d}}$ Faculty of Mining and Geology, Stip, University of "St. Cyril and Methodius", Skopje, Macedonia \\ 'Department of Geodesy, Faculty of Construction Engineering, Tirana, Albania
}

Received 25 April 2005; received in revised form 21 October 2005; accepted 28 October 2005

Available online 3 January 2006

\begin{abstract}
GPS results from 25 stations in Macedonia measured in 1996 and 2000 show that Macedonia moves SSE relative to Eurasia essentially as a single crustal piece along with parts of westernmost Bulgaria. Geological studies show active N-S normal faults and two NNW-striking right-lateral faults in western Macedonia, and NW-trending left-lateral faults SE Macedonia, with a region in central Macedonia essentially devoid of active faults. Distribution of seismic activity supports the geological studies. However, the GPS results cannot discriminate the active faulting, except perhaps in the northern part of Macedonia in the Skopje and adjacent areas, where active $\sim \mathrm{NS}$ extension occurs. Slip-rates on the strike-slip faults must be low, in the range of $0-2 \mathrm{~mm} /$ year. There is a progressive increase in GPS velocities southward in northern Greece toward the North Anatolian fault zone, across which the velocities increase and change direction dramatically.
\end{abstract}

(C) 2005 Elsevier B.V. All rights reserved.

Keywords: Macedonia; Gps results; Active tectonics; Seismicity

\section{Introduction}

Our recent studies have proposed that the southern Balkan region is part of the more regional Aegean extensional realm that we refer to as the Southern Balkan Extensional Regime (SBER: Fig. 1; Burchfiel et al., 2000; Dumurdzanov et al., 2004, 2005). Extensional tectonism has been the dominant mode of deformation within the southern Balkan region since early Cenozoic time, perhaps as early as Early or

\footnotetext{
* Corresponding author.

E-mail address: bcburch@mit.edu (B. Clark Burchfiel).
}

Middle Eocene time (Burchfiel et al., 2003; Kounov et al., 2004). Paleogene extension within the SBER followed the closing of the Vardar Ocean and may be the beginning of the extension within the Aegean extensional realm, but this interpretation is currently controversial (compare Burchfiel et al., 2000, and Kounov et al., 2004). By early or middle Miocene time, extension within the Balkans was part of an evolving extensional system that is clearly part of the Aegean realm. During late Cenozoic time the pattern of extension within the Balkans continuously evolved and can be related to complex events in the roll back of the Hellenic subducted slab both to the south and to the 


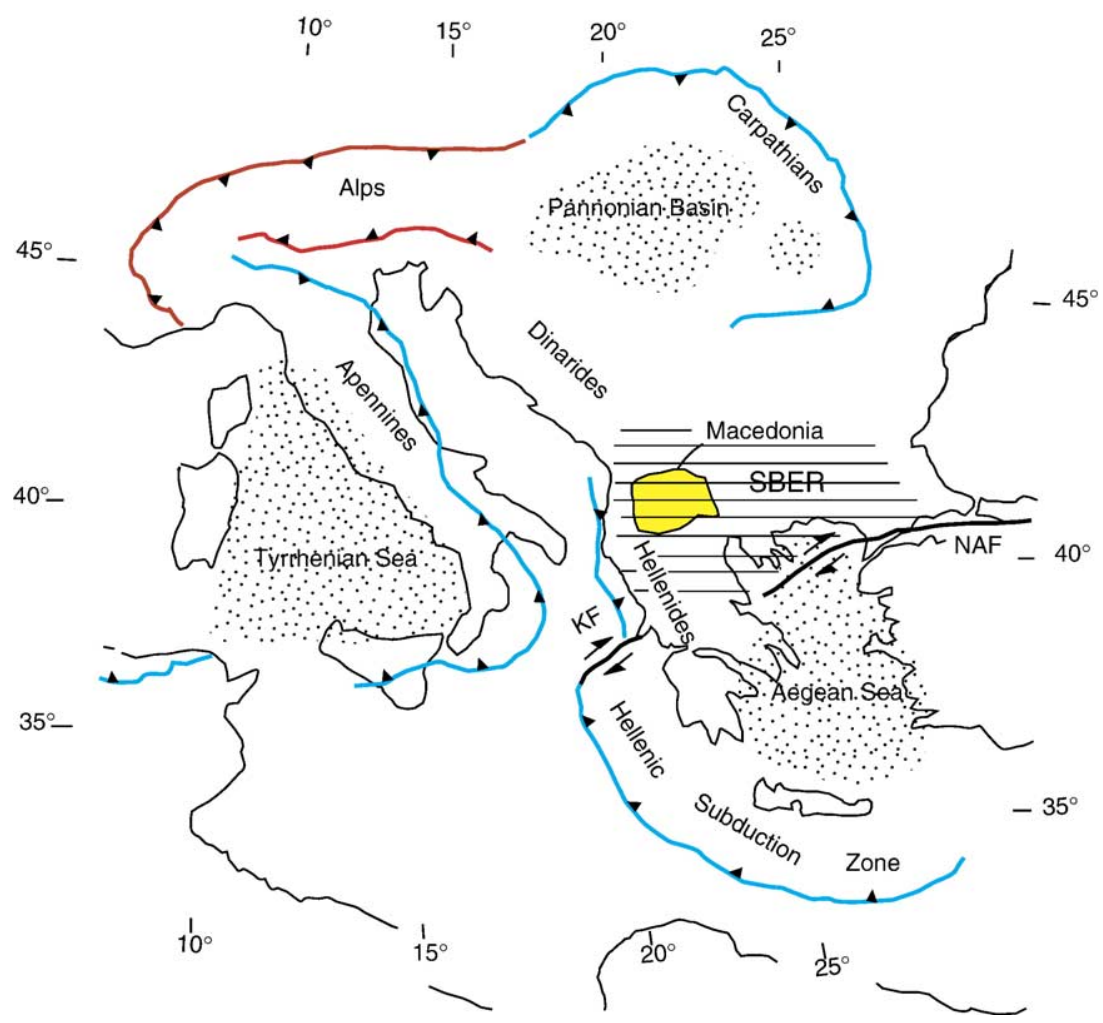

Fig. 1. Tectonic map of the Eastern Mediterranean region showing some selected tectonic features. Location of Macedonia (yellow (shaded in printed version)) is highlighted within the Southern Balkan Extensional Regime (SBER=horizontal lines). Blue lines with barbs (dashed lines with barbs in printed version) are retreating subduction boundary and red barbed lines (solid barbed lines in printed version) are advancing subduction boundaries from late Cenozoic to recent time. Dotted areas are back arc regions of late Cenozoic extension and subsidence. NAF=North Anatolian fault, $\mathrm{KF}=$ Kefalonia fault. (For interpretation of the references to colour in this figure legend, the reader is referred to the web version of this article.)

west (Dumurdzanov et al., 2005). Nowhere is this more clear than in Macedonia where late Cenozoic E-W extension shows a progressive migration toward the west where roll back of the northern Hellenic trench occurred from Paleogene to recent time. Late Cenozoic normal faults of NW to NNW strike migrated to the west from central Macedonia into eastern Albania followed to the east by $\mathrm{N}-\mathrm{S}$ extension that migrated from Bulgaria into Macedonia (Fig. 2). A major change in extension direction occurred when the North Anatolian fault entered the north Aegean region in latest Miocene time (Armijo et al., 1999; Sengor et al., 2004). At that time it has been proposed that the Aegean region began to move SSW and at least by Pliocene time began to more or less as a single plate south of the North Anatolian fault, as it does today (McClusky et al., 2000; Burchfiel et al., 2003; from data provided by D. Papanikolaou and L. Royden, personal communication). At the same time the extension direction within the Balkan system began to become more $\mathrm{N}-\mathrm{S}$, but extension proceeded at a much lower rate than southward movement of the Aegean plate. It is this pattern of extension that characterizes the active tectonics of the SBER north of the North Anatolian fault and east of the E-W extension, with a component of right-lateral strike slip, driven by trench roll back in the North Hellenic trench that affects western Macedonia and eastern Albania (Fig. 2).

\section{GPS measurements in Macedonia}

Our GPS studies in Bulgaria (Kotzev et al., 2001; Nakov, et al., 2001; Kotzev et al., 2006 - this volume) and Macedonia (this paper) have been an attempt to characterize present-day crustal movements and to relate these movements to studies of active faulting (Kotzev et al., 2006-this volume; Dumurdzanov et al., 2005). For Macedonia we used data from a 25-station GPS network surveyed twice, in 1996 by the State Department for Geodetic Survey, Republic of Macedonia, and the Bundesamt fur Kartographie und Geodasie (BKG) (Altiner et al., 1998), and in 2000 by the State Department for Geodetic Survey and MIT. In 1996 all 25 stations were occupied simultaneously and continuously for 6 days; 


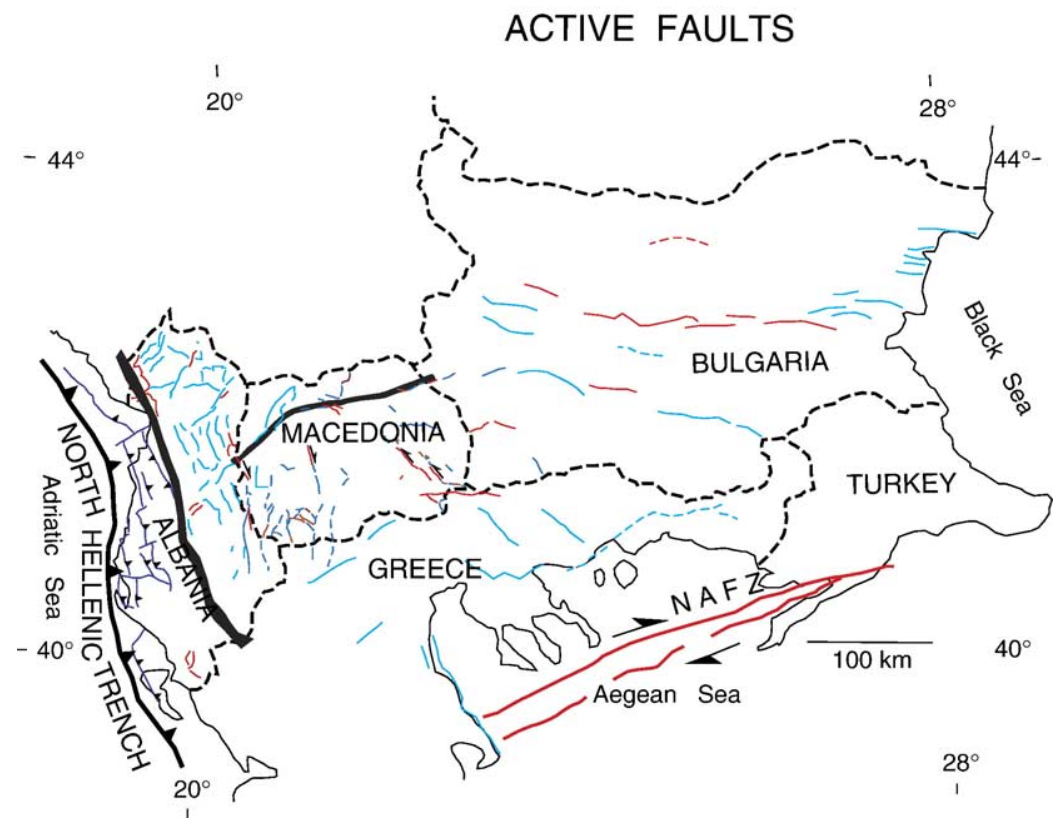

Fig. 2. Active faults in the Southern Balkan Extensional Regime. Faults are red (black thick lines in printed version) where geological evidence shows features of active fault movement. Faults in solid blue lines (black thin lines in printed version) are associated with well-developed morphological evidence for recent activity. Faults in dashed blue lines (black dashed lines in printed version) are associated with only weak morphological evidence for recent activity. Bold red lines (bold black lines in printed version) in northern Aegean Sea mark the trace of the North Anatolian fault. Shaded line trending N-S through central Albania marks the abrupt change from shortening structures to the west and $\mathrm{N}-\mathrm{S}$ trending extensional structures to the east that continue into western Macedonia. Shaded line trending NNE through northern Macedonia is the regional Elbasan-Debar-Skopje-Kjustendil fault zone of Macedonian geologists. Arrows mark the sense of displacement on strike-slip faults. (For interpretation of the references to colour in this figure legend, the reader is referred to the web version of this article.)

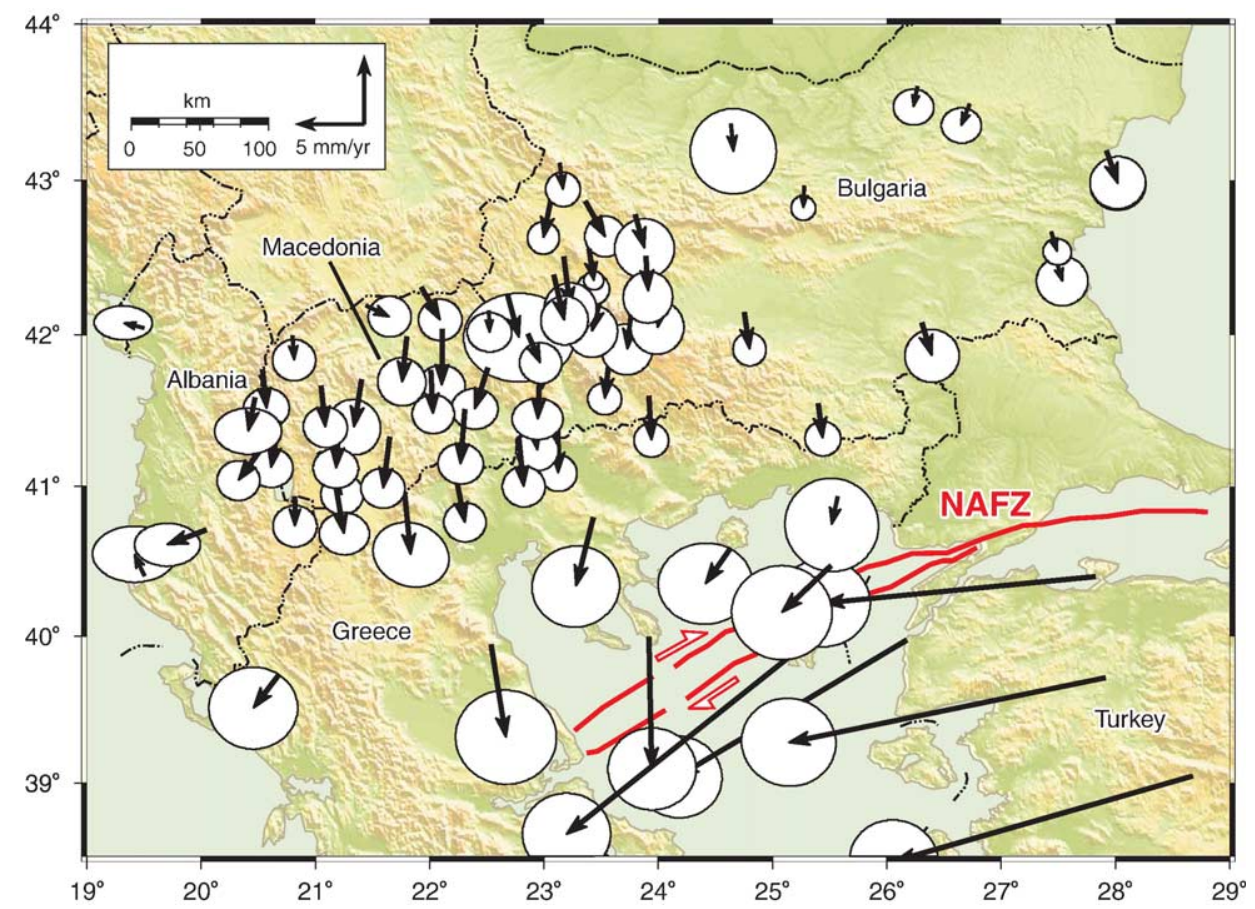

Fig. 3. GPS velocities with respect to the Eurasian reference frame defined by McClusky et al. (2000). Uncertainties are shown at $95 \%$ confidence. (Data from Macedonia and Albania, this study; from Bulgaria, Kotzev et al., 2001; from northern Greece and Turkey, McClusky et al., 2000). 


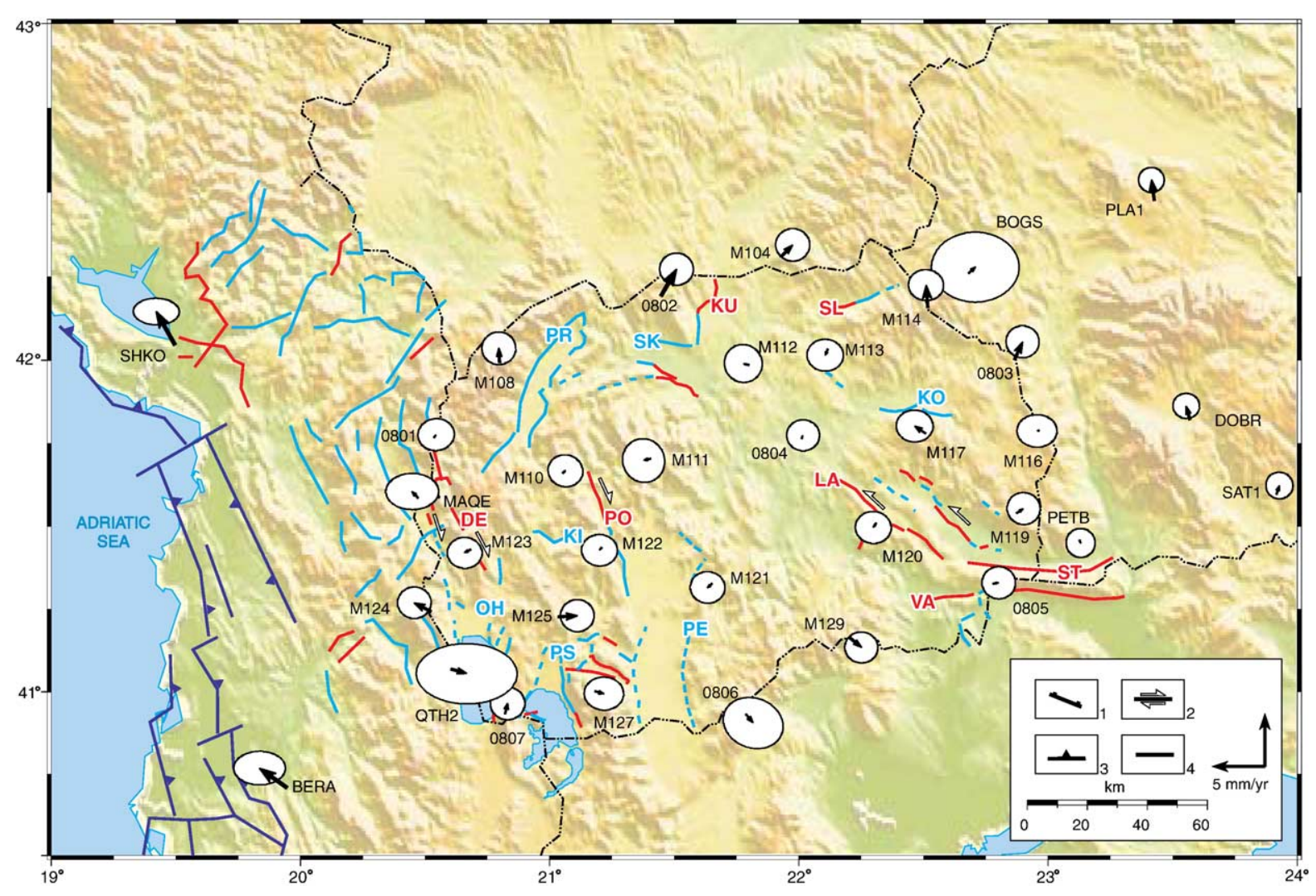

Fig. 4. GPS velocities with respect to a local frame defined by 17 stations in central Macedonia (see Table 1). Uncertainties are the same as in Fig. 3. Color scheme (black line patterns in printed version) for faults is the same as in Fig. 2.

and in 2000 these stations were occupied in groups of six for single 24-h sessions.

We analyzed the GPS data using the GAMIT/ GLOBK software (King et al., 2003; Herring, 2003) and the approach described in Kotzev et al. (2006this volume). Fig. 3 shows our estimated velocities with respect to Eurasia and Fig. 4 with respect to central Macedonia (see the discussion of reference frames in Kotzev et al., 2006-this volume). In Table 1 we list the velocities for the stations shown in the figures and also the additional stations used to define the Eurasian frame. As described in Kotzev et al., the velocity uncertainties are based on a weighting of the position uncertainties such that the uncertainties of the randomly distributed velocities of 53 stations in the stable regions of central Macedonia, southern Romania and northern Bulgaria, and western Bulgaria match our expectations. With this weighting (based on all 53 stations), the velocities of 14 of the 19 stations in central Macedonia fall within the bounds of their $70 \%$ confidence ellipses, and 17 fall within the bounds of their $95 \%$ confidence ellipses. Hence we conclude that the estimated uncertainties are realistic and provide a reliable basis for interpreting deformation outside the stable region.

\section{Interpretation}

Our geological studies, taken from Durmurdzanov et al. (2005), of active faulting within Macedonia are summarized in Fig. 5. Three categories of faults are shown; 1) faults with evidence of active faulting, such as scarps or offset streams (red), 2) faults with welldeveloped morphological expression for active faulting such as triangular facets and alluvial fans that are too small for their drainage basins, but evidence for scarps etc. are not present (solid blue), and 3) faults with well developed morphological expression for the modern topography and are only suspected to be active (dashed blue). The fault pattern shows active N-S extension in eastern Macedonia with associated NNW-striking leftlateral strike-slip faults, a region in central Macedonia characterized by almost no active faults, and a western region dominated by NNW-striking normal faults and associated strike-slip faults with right-lateral displacement. The faults in western Macedonia are responsible 
Table 1

GPS station velocities

\begin{tabular}{|c|c|c|c|c|c|c|c|c|}
\hline \multirow[t]{2}{*}{ Station } & \multirow[t]{2}{*}{ Lon. ${ }^{\circ} \mathrm{E}$} & \multirow[t]{2}{*}{ Lat. ${ }^{\circ} \mathrm{N}$} & \multicolumn{4}{|l|}{ Eurasian frame } & \multicolumn{2}{|c|}{ Macedonian-frame } \\
\hline & & & East [mm/year] & North [mm/year] & $\sigma$ East $[\mathrm{mm} /$ year $]$ & $\sigma$ North $[\mathrm{mm} /$ year $]$ & East [mm/year] & North [mm/year] \\
\hline \multicolumn{9}{|c|}{ Estimates from this solution } \\
\hline VILL & 356.05 & 40.44 & -0.3 & 0.2 & 0.3 & 0.2 & 0.3 & -4.1 \\
\hline POL2 & 74.69 & 42.68 & -1.2 & 2.9 & 0.4 & 0.4 & 4.8 & 18.5 \\
\hline KIT3 & 66.89 & 39.14 & -1.3 & 0.6 & 0.4 & 0.3 & 4.4 & 15.0 \\
\hline ZWEN & 36.76 & 55.70 & 0.4 & -0.4 & 0.3 & 0.2 & -4.0 & 7.3 \\
\hline ANKR & 32.76 & 39.89 & -20.6 & -2.2 & 1.1 & 1.0 & 19.4 & 4.4 \\
\hline AHTG & 27.95 & 42.10 & -2.2 & -1.2 & 1.4 & 1.2 & -2.1 & 4.0 \\
\hline VATG & 27.92 & 43.20 & 0.8 & -2.4 & 0.8 & 0.8 & 0.5 & 2.8 \\
\hline BUTG & 27.48 & 42.48 & 0.5 & -1.5 & 0.8 & 0.7 & 0.4 & 3.5 \\
\hline BURG & 27.44 & 42.67 & 0.4 & -1.4 & 0.4 & 0.4 & 0.3 & 3.6 \\
\hline SHUM & 26.73 & 43.49 & -0.6 & -1.5 & 0.6 & 0.5 & -1.1 & 3.3 \\
\hline TOPO & 26.31 & 42.08 & 0.7 & -2.4 & 0.8 & 0.8 & 0.7 & 2.4 \\
\hline TSAR & 26.27 & 43.60 & -0.3 & -1.5 & 0.6 & 0.5 & -0.9 & 3.2 \\
\hline BUCU & 26.13 & 44.46 & -0.7 & -1.2 & 0.5 & 0.5 & -1.6 & 3.5 \\
\hline MOMC & 25.40 & 41.55 & 0.3 & -2.5 & 0.5 & 0.5 & 0.5 & 2.0 \\
\hline GABR & 25.28 & 42.96 & -0.1 & -1.6 & 0.4 & 0.4 & -0.5 & 2.8 \\
\hline TATA & 25.18 & 43.58 & 0.0 & 0.5 & 0.9 & 0.8 & -0.7 & 4.9 \\
\hline PLDV & 24.75 & 42.15 & 0.4 & -2.7 & 0.5 & 0.5 & 0.3 & 1.6 \\
\hline KAIL & 24.63 & 43.36 & 0.2 & -2.0 & 1.3 & 1.3 & -0.4 & 2.3 \\
\hline METS & 24.40 & 60.22 & 0.3 & -1.1 & 0.2 & 0.2 & -6.8 & 3.1 \\
\hline VETR & 24.06 & 42.29 & -0.5 & -2.7 & 0.8 & 0.8 & -0.7 & 1.4 \\
\hline MUHO & 23.93 & 42.43 & -0.2 & -2.0 & 0.7 & 0.8 & -0.4 & 2.0 \\
\hline SAT1 & 23.92 & 41.60 & 0.2 & -3.2 & 0.5 & 0.5 & 0.3 & 0.8 \\
\hline BELI & 23.89 & 42.51 & 0.2 & -2.5 & 1.2 & 1.2 & -0.1 & 1.5 \\
\hline VITA & 23.80 & 42.78 & 0.7 & -2.4 & 0.9 & 0.9 & 0.3 & 1.6 \\
\hline BELM & 23.76 & 42.14 & -0.3 & -2.6 & 0.8 & 0.8 & -0.4 & 1.4 \\
\hline VERI & 23.73 & 42.48 & 2.6 & -4.0 & 0.8 & 0.8 & 2.4 & 0.0 \\
\hline BUHO & 23.57 & 42.77 & -0.8 & -3.8 & 1.0 & 1.1 & -1.2 & 0.1 \\
\hline DOBR & 23.57 & 41.82 & -0.3 & -2.7 & 0.5 & 0.5 & -0.3 & 1.2 \\
\hline KOZN & 23.55 & 42.99 & -0.1 & -1.7 & 1.1 & 1.1 & -0.6 & 2.3 \\
\hline MALA & 23.51 & 42.27 & -0.7 & -2.8 & 0.8 & 0.8 & -0.9 & 1.1 \\
\hline LOZE & 23.49 & 42.60 & -0.1 & -3.0 & 0.9 & 0.9 & -0.5 & 0.9 \\
\hline PLA1 & 23.43 & 42.48 & 0.0 & -2.0 & 0.5 & 0.5 & -0.2 & 1.9 \\
\hline SOFI & 23.40 & 42.56 & 0.3 & -2.3 & 0.3 & 0.3 & 0.0 & 1.6 \\
\hline VLTR & 23.36 & 42.87 & 1.4 & -2.5 & 0.6 & 0.6 & 1.0 & 1.3 \\
\hline CHER & 23.28 & 42.56 & -1.9 & -2.2 & 0.9 & 0.9 & -2.2 & 1.6 \\
\hline SAPA & 23.25 & 42.28 & 0.6 & -1.9 & 0.7 & 0.7 & 0.3 & 2.0 \\
\hline PADA & 23.18 & 42.14 & -0.5 & -3.6 & 0.9 & 0.9 & -0.6 & 0.2 \\
\hline BOSN & 23.17 & 42.51 & 0.5 & -3.7 & 0.8 & 0.8 & 0.2 & 0.1 \\
\hline BERK & 23.14 & 43.11 & 0.2 & -1.9 & 0.5 & 0.5 & -0.3 & 1.9 \\
\hline PECH & 23.13 & 41.46 & 0.0 & -4.0 & 0.6 & 0.5 & 0.1 & -0.3 \\
\hline DELA & 23.09 & 42.39 & 0.8 & -3.3 & 0.7 & 0.7 & 0.5 & 0.5 \\
\hline KRAL & 23.08 & 42.57 & -0.2 & -4.0 & 0.7 & 0.8 & -0.5 & -0.3 \\
\hline BANK & 23.07 & 42.72 & 0.0 & -2.6 & 0.8 & 0.8 & -0.4 & 1.1 \\
\hline SLIV & 23.06 & 42.86 & -0.5 & -2.6 & 0.5 & 0.5 & -1.0 & 1.2 \\
\hline M116 & 22.96 & 41.79 & -0.2 & -3.8 & 0.8 & 0.6 & -0.2 & 0.0 \\
\hline FROL & 22.94 & 42.13 & 0.3 & -2.8 & 0.7 & 0.7 & 0.1 & 0.9 \\
\hline BREZ & 22.90 & 42.75 & 0.2 & -4.8 & 0.8 & 0.8 & -0.2 & -1.1 \\
\hline M119 & 22.88 & 41.54 & 0.6 & -3.3 & 0.6 & 0.6 & 0.6 & 0.4 \\
\hline 0803 & 22.86 & 42.00 & 0.9 & -2.1 & 0.6 & 0.6 & 0.8 & 1.6 \\
\hline CARV & 22.82 & 42.36 & 0.9 & -2.3 & 0.8 & 0.8 & 0.6 & 1.4 \\
\hline 0805 & 22.78 & 41.33 & 0.4 & -3.6 & 0.6 & 0.6 & 0.5 & 0.1 \\
\hline VARB & 22.77 & 43.61 & -0.1 & -1.9 & 0.5 & 0.5 & -0.9 & 1.7 \\
\hline DSEC & 22.72 & 42.68 & 0.1 & -3.9 & 0.8 & 0.8 & -0.3 & -0.2 \\
\hline ZEME & 22.70 & 42.50 & 1.1 & -2.4 & 0.7 & 0.7 & 0.8 & 1.2 \\
\hline BOGS & 22.68 & 42.26 & 0.8 & -3.1 & 1.6 & 1.3 & 0.6 & 0.6 \\
\hline
\end{tabular}


Table 1 (continued)

\begin{tabular}{|c|c|c|c|c|c|c|c|c|}
\hline \multirow[t]{2}{*}{ Station } & \multirow[t]{2}{*}{ Lon. ${ }^{\circ} \mathrm{E}$} & \multirow[t]{2}{*}{ Lat. ${ }^{\circ} \mathrm{N}$} & \multicolumn{4}{|l|}{ Eurasian frame } & \multicolumn{2}{|c|}{ Macedonian-frame } \\
\hline & & & East [mm/year] & North [mm/year] & $\sigma$ East $[\mathrm{mm} /$ year $]$ & $\sigma$ North $[\mathrm{mm} /$ year] & East [mm/year] & North [mm/year] \\
\hline M114 & 22.52 & 42.16 & 0.1 & -1.6 & 0.7 & 0.6 & -0.1 & 2.0 \\
\hline M117 & 22.51 & 41.78 & -0.9 & -2.9 & 0.7 & 0.6 & -1.0 & 0.7 \\
\hline M120 & 22.31 & 41.51 & -0.3 & -3.9 & 0.7 & 0.6 & -0.3 & -0.4 \\
\hline M129 & 22.21 & 41.16 & 0.9 & -4.3 & 0.6 & 0.6 & 1.0 & -0.8 \\
\hline M113 & 22.12 & 42.03 & -0.1 & -4.0 & 0.7 & 0.6 & -0.2 & -0.6 \\
\hline 0804 & 22.01 & 41.77 & 0.2 & -3.1 & 0.6 & 0.6 & 0.1 & 0.3 \\
\hline M104 & 21.93 & 42.31 & 1.4 & -2.4 & 0.6 & 0.6 & 1.1 & 1.1 \\
\hline M112 & 21.80 & 41.99 & -0.3 & -3.3 & 0.7 & 0.7 & -0.5 & 0.1 \\
\hline 0806 & 21.79 & 40.93 & 0.4 & -4.2 & 1.1 & 1.0 & 0.7 & -0.8 \\
\hline M121 & 21.65 & 41.33 & -0.5 & -3.7 & 0.7 & 0.6 & -0.4 & -0.4 \\
\hline 0802 & 21.45 & 42.19 & 1.7 & -0.8 & 0.6 & 0.6 & 1.4 & 2.5 \\
\hline M111 & 21.40 & 41.70 & -0.6 & -3.4 & 0.8 & 0.8 & -0.6 & -0.2 \\
\hline M122 & 21.21 & 41.44 & -0.2 & -3.4 & 0.7 & 0.6 & -0.2 & -0.2 \\
\hline M127 & 21.18 & 41.00 & 0.6 & -3.4 & 0.7 & 0.6 & 0.8 & -0.2 \\
\hline M110 & 21.05 & 41.66 & 0.3 & -2.9 & 0.7 & 0.6 & 0.2 & 0.2 \\
\hline M125 & 21.03 & 41.23 & 1.7 & -3.0 & 0.6 & 0.6 & 1.8 & 0.1 \\
\hline JOZE & 21.03 & 52.10 & 0.2 & 0.1 & 0.3 & 0.3 & -4.0 & 3.3 \\
\hline 0807 & 20.82 & 40.93 & 0.0 & -2.1 & 0.7 & 0.6 & 0.2 & 1.0 \\
\hline M108 & 20.80 & 41.99 & 0.1 & -1.7 & 0.6 & 0.6 & -0.1 & 1.3 \\
\hline M123 & 20.68 & 41.43 & -0.6 & -3.3 & 0.7 & 0.6 & -0.6 & -0.3 \\
\hline QTH2 & 20.60 & 41.07 & 1.3 & -3.4 & 1.9 & 1.1 & 1.4 & -0.4 \\
\hline 0801 & 20.54 & 41.77 & 0.3 & -2.8 & 0.7 & 0.6 & 0.2 & 0.2 \\
\hline M124 & 20.52 & 41.24 & -1.6 & -2.2 & 0.6 & 0.6 & -1.5 & 0.8 \\
\hline MAQE & 20.47 & 41.59 & -0.5 & -2.4 & 1.0 & 0.7 & -0.5 & 0.6 \\
\hline BERA & 19.95 & 40.71 & -2.8 & -1.1 & 1.0 & 0.6 & -2.5 & 1.8 \\
\hline VLOR & 19.51 & 40.41 & -0.7 & 1.5 & 1.2 & 0.8 & -0.3 & 4.2 \\
\hline SHKO & 19.50 & 42.05 & -1.4 & 0.4 & 0.9 & 0.5 & -1.7 & 3.1 \\
\hline TROM & 18.94 & 69.66 & -0.6 & 1.0 & 0.3 & 0.3 & 11.4 & 3.5 \\
\hline BOR1 & 17.07 & 52.28 & 0.3 & 0.1 & 0.2 & 0.2 & -4.1 & 2.1 \\
\hline GRAZ & 15.49 & 47.07 & 0.2 & 0.4 & 0.2 & 0.2 & -2.2 & 1.8 \\
\hline POTS & 13.07 & 52.38 & -0.2 & 0.1 & 0.5 & 0.5 & -4.7 & 0.9 \\
\hline WTZR & 12.88 & 49.14 & 0.1 & 0.2 & 0.2 & 0.2 & -3.1 & 0.9 \\
\hline ONSA & 11.93 & 57.40 & -0.7 & -0.6 & 0.2 & 0.2 & -7.2 & -0.2 \\
\hline NYAL & 11.87 & 78.93 & 0.3 & -0.8 & 0.3 & 0.3 & 13.8 & -0.4 \\
\hline MEDI & 11.65 & 44.52 & 1.4 & 2.2 & 0.3 & 0.3 & -0.1 & 2.5 \\
\hline GRAS & 6.92 & 43.76 & 0.0 & 0.2 & 0.3 & 0.3 & -1.0 & -0.9 \\
\hline KOSG & 5.81 & 52.18 & 0.1 & 0.3 & 0.5 & 0.5 & -4.3 & -1.1 \\
\hline BRUS & 4.36 & 50.80 & -0.3 & -0.6 & 0.2 & 0.2 & -4.1 & -2.4 \\
\hline HERS & 0.34 & 50.87 & -0.1 & 0.2 & 1.9 & 1.8 & -3.8 & -2.9 \\
\hline \multicolumn{9}{|c|}{ Estimates from McClusky et al. (2000) } \\
\hline DMIR & 28.67 & 39.05 & -21.5 & -6.2 & 1.3 & 1.2 & 20.2 & -0.8 \\
\hline MAER & 27.96 & 40.97 & 2.0 & -1.0 & 1.4 & 1.4 & 2.5 & 4.2 \\
\hline BALI & 27.91 & 39.72 & -22.9 & -4.7 & 1.4 & 1.3 & 21.8 & 0.5 \\
\hline AKGA & 27.87 & 39.01 & -20.9 & -10.2 & 1.3 & 1.3 & 19.6 & -5.1 \\
\hline CAMK & 27.84 & 37.20 & -16.7 & -24.8 & 1.5 & 1.5 & 14.7 & -19.7 \\
\hline ERDE & 27.82 & 40.40 & -19.6 & -1.9 & 1.4 & 1.3 & 18.9 & 3.2 \\
\hline DEMI & 27.78 & 41.83 & 0.1 & -0.7 & 1.3 & 1.3 & 0.3 & 4.4 \\
\hline ALAN & 27.42 & 39.78 & -23.7 & -9.0 & 1.5 & 1.5 & 22.8 & -3.9 \\
\hline YENB & 27.39 & 40.81 & -5.0 & -4.4 & 1.5 & 1.5 & -4.4 & 0.6 \\
\hline YAYA & 27.32 & 39.02 & -21.5 & -13.0 & 1.3 & 1.3 & 20.2 & -8.0 \\
\hline KIRE & 27.22 & 39.90 & -19.8 & -8.0 & 1.3 & 1.2 & 18.9 & -3.0 \\
\hline DOKU & 26.71 & 40.74 & -4.5 & -2.7 & 1.4 & 1.4 & -3.9 & 2.1 \\
\hline LESV & 26.45 & 39.23 & -21.0 & -12.5 & 1.3 & 1.2 & 19.9 & -7.8 \\
\hline SUBA & 26.17 & 39.97 & -16.5 & -9.9 & 1.3 & 1.2 & 15.7 & -5.2 \\
\hline ASKT & 25.57 & 40.93 & -0.4 & -2.0 & 1.4 & 1.4 & 0.0 & 2.5 \\
\hline SMTK & 25.51 & 40.47 & -3.5 & -3.4 & 1.5 & 1.4 & -2.9 & 1.1 \\
\hline
\end{tabular}


Table 1 (continued)

\begin{tabular}{|c|c|c|c|c|c|c|c|c|}
\hline \multirow[t]{2}{*}{ Station } & \multirow[t]{2}{*}{ Lon. ${ }^{\circ} \mathrm{E}$} & \multirow[t]{2}{*}{ Lat. ${ }^{\circ} \mathrm{N}$} & \multicolumn{4}{|l|}{ Eurasian frame } & \multicolumn{2}{|c|}{ Macedonian-frame } \\
\hline & & & East [mm/year] & North [mm/year] & $\sigma$ East $[\mathrm{mm} /$ year $]$ & $\sigma$ North $[\mathrm{mm} /$ year $]$ & East [mm/year] & North [mm/year] \\
\hline LIMN & 25.13 & 39.85 & -16.0 & -12.7 & 1.3 & 1.2 & 15.1 & -8.4 \\
\hline THAS & 24.63 & 40.59 & -1.8 & -2.6 & 1.4 & 1.2 & -1.3 & 1.7 \\
\hline STHN & 23.92 & 39.99 & 0.2 & -9.5 & 1.3 & 1.2 & 0.9 & -5.5 \\
\hline SOXO & 23.43 & 40.79 & -1.3 & -4.9 & 1.3 & 1.2 & -0.9 & -1.1 \\
\hline PLAN & 23.42 & 42.48 & -2.8 & -2.3 & 1.6 & 1.5 & -3.1 & 1.6 \\
\hline KYRA & 22.98 & 36.31 & -16.2 & -24.6 & 1.4 & 1.3 & 14.1 & -20.9 \\
\hline KRNA & 22.54 & 39.94 & 1.1 & -6.7 & 1.5 & 1.4 & 1.7 & -3.1 \\
\hline KRTS & 20.67 & 39.73 & -1.8 & -2.3 & 1.3 & 1.2 & -1.1 & 0.7 \\
\hline
\end{tabular}

1. The uncertainties shown are for the solution in the Eurasian reference frame. For stations in Macedonia, they are about $10 \%$ smaller when the velocities are expressed in the Macedonian frame. For all stations, the correlations between the $\mathrm{N}$ and $\mathrm{E}$ velocity estimates are less than 0.05 and hence are omitted.

2. Stations used to realize the Eurasian frame: VILL, ONSA, ZWEN, GRAS, JOZE, BRUS, BOR1, GRAZ, WTZR.

3. Stations used to realize the Macedonia frame: 0801, 0804, 0807, M108, M110, M111, M112, M113, M116, M117, M119, M120, M121, M122, M123, M125, M127.

4. Stations used to tie our velocities to those of McClusky et al. (2000): KIT3, ZWEN, ANKR, BURG, METS, JOZE, TROM, BOR1, GRAZ, POTS, WTZR, ONSA, NYAL, KOSG, BRUS, HERS.

for the great local relief along grabens, some of which contain lakes. Faults in northwestern Macedonia curve from their $\mathrm{N}-\mathrm{S}$ strike to more $\mathrm{E}-\mathrm{W}$ strike and are strongly influenced by the structural anisotropy of the crust in this region which shows the same change in strike (Dumurdzanov et al., 2005). In this part of Macedonia, the active Skopje graben trends E-W and is the locus of active faults of similar trend.

Seismicity with the Southern Balkan Extensional Regime is variable in its distribution within Macedonia. Earthquake activity is most abundant in western Macedonia and adjacent Albania (Figs. 6 and 7) and less frequent in eastern Macedonia and nearly absent in central Macedonia (excluding the Skopje area). This distribution is consistent with the geological observations of active faulting shown in Figs. 2, 5 and 7. Thus to a first order seismicity and geology are in general agreement, although most of the earthquakes in Macedonia are too small analyze for fault mechanisms.

The GPS results show an almost uniform southward velocity of 3-4 mm/year relative to stable Europe (Fig. 3 ). Macedonia thus appears to move as a single crustal unit to the south. Within most of Macedonia the active faults shown by either the geology or the seismicity cannot be located within the uncertainties of the GPS data (compare Figs. 3, 5-7). This is unexpected since

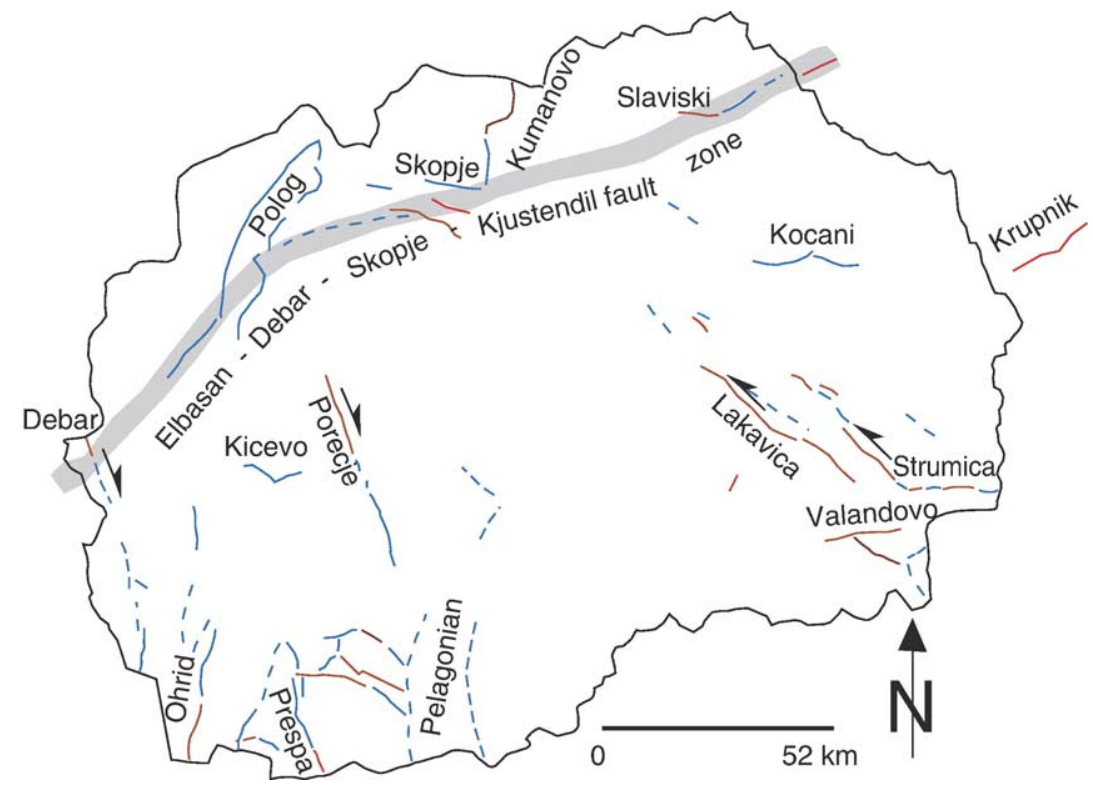

Fig. 5. Active faults within Macedonia. Color scheme (black line patterns in printed version) for faults is the same as in Fig. 2. 


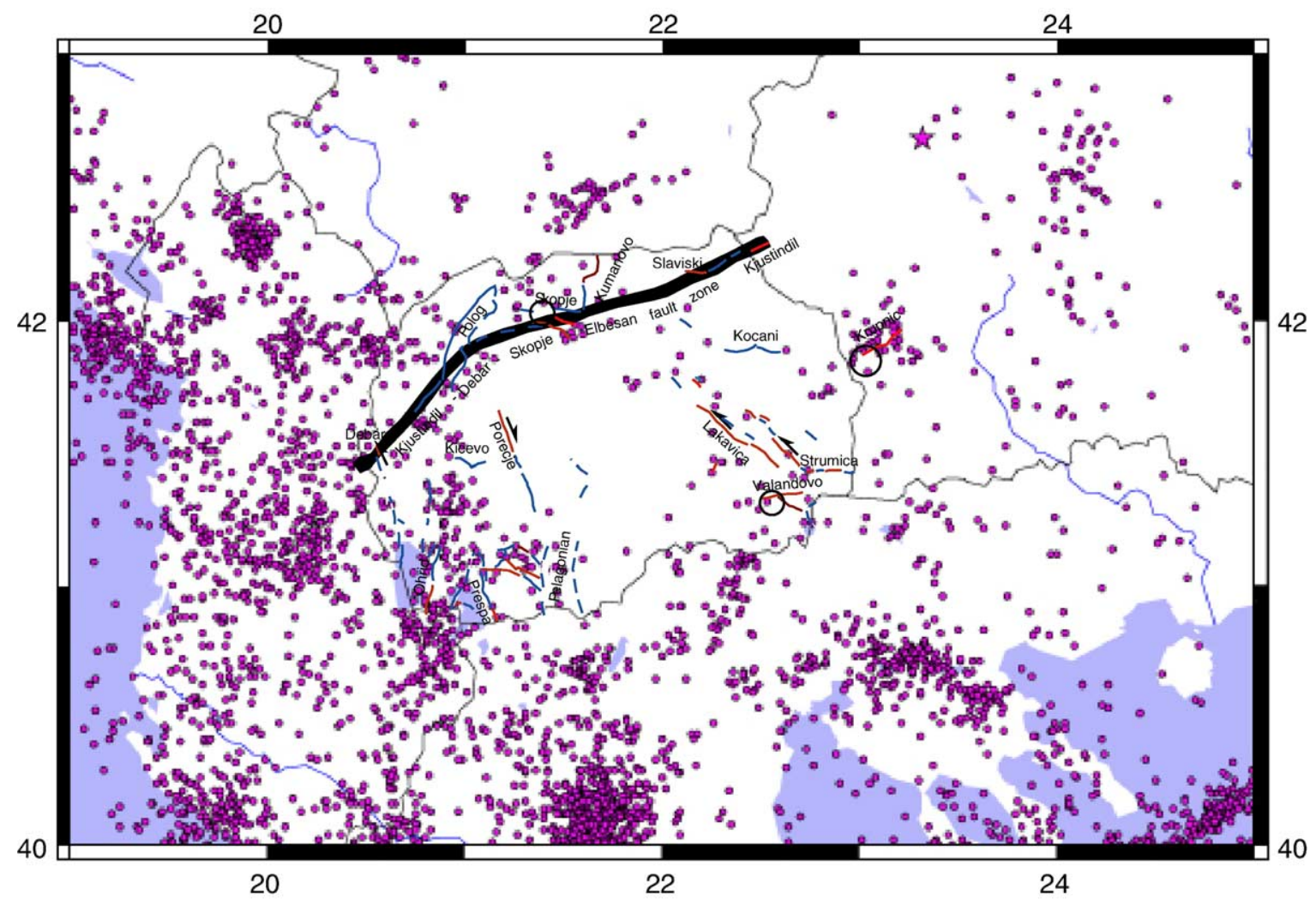

Fig. 6. Location of earthquakes of $M>3.0$ in Macedonia and surrounding region for the period 1976 to 2004 superposed on the map of active faults in Fig. 5. Three large earthquakes that occurred in the last century are shown by the black circles; Krupnik in Bulgaria [1904] $M=6.9$ according to (Meyer et al., 2002); and $M=7.5-7.8$ according to (Ranguleov et al., 2001); Skopje [1963] $M=6.1$; and Valandovo [1932] $M=6.5-6.8$.

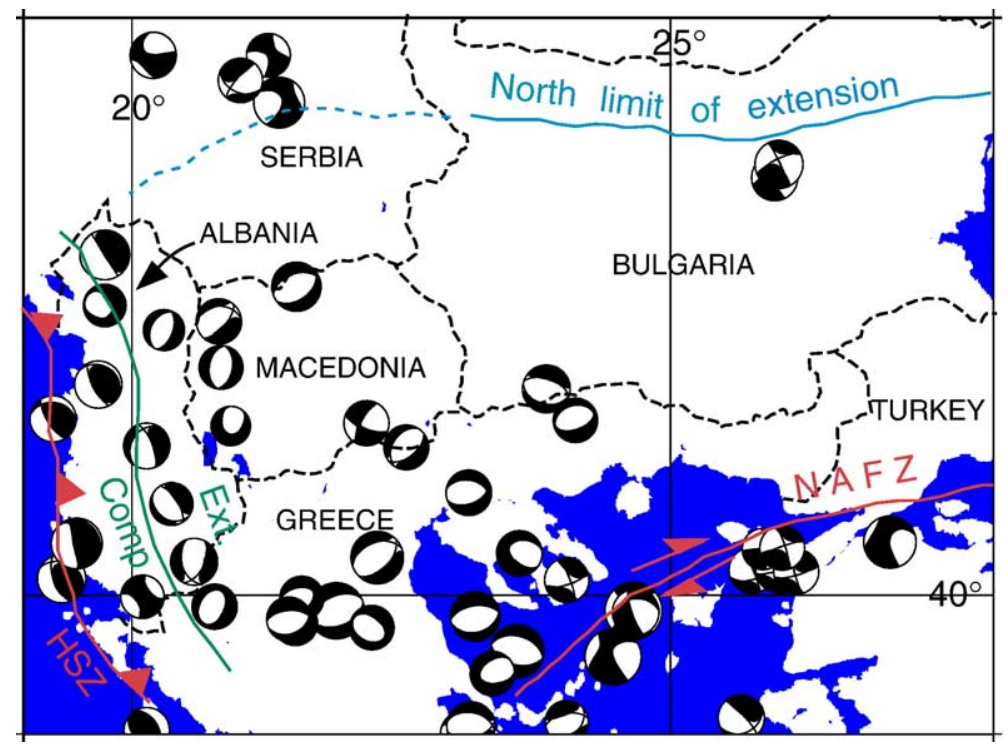

Fig. 7. Earthquake focal mechanisms for Macedonia and surrounding region. Only a few earthquakes are large enough to determine a mechanism. The northern limit of extension within the SBER and the boundary between extensional and compressional faults in Albania as determined from active faulting are shown. HSZ=Northern Hellenic subduction zone, NAFZ=North Anatolian fault zone. 
the area shows considerable active tectonism. The only area where there is a suggestion of velocity differences is within northern Macedonia along a general $\mathrm{E}-\mathrm{W}$ trend that passes through the Skopje graben, the site of the destructive 1963 magnitude 6.1 earthquake. Here the data suggest, but cannot prove a change in velocity that indicates N-S extension with an associated leftlateral component. The Skopje graben lies along the Kjustindil-Skopje-Debar-Elbasan fault zone of tectonic activity postulated for many decades by Macedonian geologists. It is also of note that one of the largest earthquake in Europe during the 20th century, was at Krupnik in western Bulgaria adjacent to Macedonia, $M=6.9$ (Meyer et al., 2002) or $M=7.5-7.9$ (Ranguelov et al., 2001). Our GPS study in Bulgaria (Fig. 3; Kotzev et al., 2006 - this volume) also shows southward velocities similar to those in Macedonia and also does not show the velocity differences that would be expected from $\mathrm{N}-\mathrm{S}$ extension along the Krupnik fault.

When GPS stations in northern Greece are considered, there is a gradual increase in velocity to $25 \mathrm{~mm} /$ year before reaching the North Anatolian fault (Fig. 3). This increase in velocity to the south is consistent with the $\mathrm{E}-\mathrm{W}$ trend of active faults in southern Macedonia, adjacent southwestern Bulgaria, and northern Greece. Focal mechanisms determined for the region are also consistent with this interpretation, showing general NS extension, locally with a right-lateral strike-slip component (Fig. 7). The GPS velocities and focal mechanisms can be interpreted to suggest that the Aegean plate (see above) is now moving south-southwest and pulling the South Balkan lithosphere away from the region north of the South Balkan extensional regime. Focal mechanisms for the region show E-W convergence at the Albanian coast with the rapid change in central Albania to $\mathrm{E}-\mathrm{W}$ extension in eastern Albania (Fig. 7). There is also some suggestion in both the seismic and a stronger indication from the GPS data for a component of right-lateral strike-slip within western Albania (Fig. 4).

\section{Conclusions}

Although there is general agreement between the geology of active faulting and the distribution and analysis of some seismic data for Macedonia, the uncertainties in the GPS velocity estimates are large enough that they cannot discriminate clearly the active tectonics. This is unfortunate, because Macedonia and adjacent Bulgaria have been the location of large and destructive earthquakes during the last century. If monitoring for potential future earthquake hazards is to be attempted, it will require continued GPS measurements within the region to reduce the uncertainty in the calculated crustal velocities and continued geological studies to better understand the history on active faults.

\section{Acknowledgements}

This study is part of an international cooperative project to understand the Cenozoic and active tectonics of the Southern Balkan peninsula. It includes the Department of Geodesy, Construct Engineering Faculty, Tirana, Albania, the Central Laboratory of Geodesy, Bulgarian Academy of Sciences, Bulgaria, State Department for Geodetic Survey, Macedonia; Faculty of Mining and Geology, Stip, Macedonia; and the Department of Earth and Planetary Sciences, M.I.T., USA. We are grateful to Shimon Wdowinski for a helpful review. Figs. 3 and 4 were generated using the Generic Mapping Tools (Wessel and Smith, 1998), Release 4.0. This study was supported by NSF Grant EAR-9903021.

\section{References}

Altiner, Y., Becker, M., Dzonov, D., Postolovski, V., Seeger, H., Todosov, A., 1998. Results of the EUREF-FYROM-GPS campaign: in EUREF Publication No. 7/11. Mitteilungen des Bundesamt fur Kartographie und Geodasie, Band, Frankfurt 6, pp. $59-78$.

Armijo, R., Meyer, B., Hubert, A., Barka, A., 1999. Westward propagation of the North Anatolian fault into the northern Aegean: timing and kinematics. Geology 27, 267-270.

Burchfiel, B.C., Nakov, R., Tzankov, T., Royden, L.H., 2000. Cenozoic extension in Bulgaria and northern Greece: the northern part of the Aegean extensional regime. In: Bozkurt, E., Winchester, J.A., Piper, J.D.A. (Eds.), Tectonics and Magmatism in Turkey and the Surrounding Area, Geol. Soc. London, Spec. Pub. 173, pp. $325-352$.

Burchfiel, B.C., Nakov, R., Tzankov, T., 2003. Evidence from the Mesta half-graben, SW Bulgaria, for the late Eocene beginning of Aegean extension in the Central Balkan Peninsula. Tectonophysics $375,61-76$.

Durmurdzanov, N., Serafimovski, T., Burchfiel, B.C., 2004. Evolution of the Neogene-Pleistocene basins of Macedonia. Geol. Soc. America Digital Map and Chart Series MC01 20 pages.

Dumurdzanov, N., Serafimovski, T., Burchfiel, B.C., 2005. Cenozoic tectonics of Macedonia and its relation to the South Balkan extensional regime. Geosphere 1 (1), 1-22. doi:10.1130/GES00006.1.

Herring, T.A., 2003. GLOBK: Global Kalman filter VLBI and GPS analysis program, Release 10.1, Mass. Inst. of Technol., Cambridge.

King, R.W., Bock, Y., Herring, T.A., McClusky, S.C., 2003. Documentation for the GAMIT GPS software analyse program, release 10.1. Mass. Inst. of Technol., Cambridge.

Kotzev, V., Nakov, R., Burchfiel, B.C., King, R., Reilinger, R., 2001. GPS study of active tectonics in Bulgaria: results from 1996 to 1998. J. Geodyn. 31 (2), 189-200. 
Kotzev, V., Nakov, R., Georgiev, Tz., Burchfiel, B.C., King, R.W., 2006 - this volume. Crustal motion and strain accumulation in western Bulgaria. Tectonophysics 413, 127-145. doi:10.1016/ j.tecto.2005.10.040.

Kounov, A., Seward, D., Bernouli, D., Burg, J.-P., Ivanov, Z., 2004. Thermotectonic evolution of an extensional dome: the Cenozoic Osogovo-Lisets core complex (Kriashte zone, western Bulgaria). Int. J. Earth Sci. 93, 1008-1024.

McClusky, S., Balassanian, S., Barka, A., Demir, C., Erginav, S., Georgiev, I., Gurkan, O., Hamburger, M., Hurst, K., Kahle, H., Kastens, K., Kekelidze, G., King, R., Kotzev, V., Lenk, O., Mahmoud, S., Mishin, A., Nadarya, M., Ouzounis, A., Paradissis, D., Peter, Y., Prilepin, M., Reilinger, R., Sanli, I., Seeger, H., Tealeb, A., Toksoz, M.N., Veis, G., 2000. Global Positioning System constraints on plate kinematics and dynamics in the eastern Mediterranean and Caucasus. J. Geophys. Res. 105, 5695-5719.
Meyer, B., Armijo, R., Dimitrov, D., 2002. Active faulting in SW Bulgaria: possible surface rupture of the 1904 Struma earthquakes. Geophys. J. Int. 148, 246-255.

Nakov, R., Kotzev, V., Burchfiel, B.C., King, R.W., 2001. GPS data on the active tectonics of the Bulgarian Rhodopes. Geologica Balkanica 31 (1-2), 123-125.

Ranguelov, B., Rizhikova, S., Toteva, T., 2001. The Earthquake (7.8) Source Zone-southwest Bulgaria: Professor Marin Drinov. Academic Publishing House, Sofia. 279 pages.

Sengor, A.M.C., Tuysuz, O., Imren, C., Sakinc, M., Ekyidogan, H., Gorur, N., Le Pichon, X., Rangin, C., 2004. The North Anatolian Fault: a new look. Annu. Rev. Earth Planet. Sci. 32, 1-75.

Wessel, P., Smith, W.H.F., 1998. New, improved version of the generic mapping tools released. EOS Trans. AGU 79, 579. 